\title{
田中正造の「治水論」と現代への継承
}

\section{Shozo Tanaka's Flood Control Theory and Succession to Present Age}

中村 愛子* 下村 彰男**

Aiko NAKAMURA Akio SHIMOMURA

\begin{abstract}
The starting point of the pollution of our country is an Ashio mineral pollution event of the 19th century. Shozo Tanaka described flood control theory about the necessity of the protection of natural environment through practice by this event. The purpose of the present study is to consider how to succeed to from Tanaka's flood control theory to a modern citizen volunteer concretely. As a result, Shozo Tanaka's flood control theory has four sides of "Traditional river technology by character of geographical features and water", "Erosion control as the head of a river training", "Flood control the mountain and river on e arth", and "Ideal way of the man activity that enjoys the life of the natural gift". At the present period, "Watarasegawakenky ukai', which was succeeded to through elaborate study of Shozo Tanaka's thoughts, was the center of the group that developed with the activity as a recovery of natural environment. Tanaka described the ideal way of the flood control and the man activity along working of natural environment. On the other hand, it was considered that a present civic group aimed at the recovery for past natural environment, and was adapting oneself to present natural environment.
\end{abstract}

Keywords: Shozo Tanaka, Soil and water conservation theory, Protection theory, Traditional river technology, civic group キーワード：田中正造, 治山治水論, 保護論, 伝統的河川工法, 市民団体

\section{1. 序論}

わが国の公害の原点は 19 世紀の足尾鉱毒事件である，とされ ている。田中正造（以下，田中）は, 鉱毒事件の下流域被害民の 立場から鉱毒反対運動を展開し，「治水論」を述べた人物である。 田中の「治水論」は, その後の河川計画に取り入れられること はなかった。しかし, 近年河川法の改正により環境の項目が加え られ, 田中の住民の立場から保護を訴えた「治水論」の内容は, 今後の方向性を検討する上でも貴重な論点となる。また，田中は， 小学校教育で既に取り上げられている人物であることから, 田中 の思想の再評価は, 今後必要となるわが国の環境問題の学習の一 助になるものと考えられる。

田中の義人像としての人物や人権・自治・平和・生命尊重思想 などの政治思想に関しては数多くの研究がある。その中で「治水 論」の内容は, 水の思想として指摘されている ${ }^{1)}$ 。中村ら $(20$ 09) ${ }^{2)}$ では, 市民団体が田中の「治水論」を治山治水論として評 価し, 植樹ボランティアが活動の中に受容した経緯を追っている。 さらなる展開として, 田中の計画者としての立場や技術そして 「治水論」における河川工学的な計画思想の存在について考察す る必要性が出てきた。

本研究では, 足尾鉱毒事件の被害民の立場から河川流域の保護 の必要性について実践を通して述べた田中正造を取り上げる。そ して, 現代の渡良瀬川流域の市民団体の築いている河川流域計画 思想へ, 具体的に田中のどの要素を受け継いで継承しているのか, その特徴と意義について考察することを目的とした。

主なデー夕は, 文書とする。田中に関しては日記や書簡が集録 された,「田中正造全集」という全 19 巻からなる著作集が発刊さ れている。現代の市民団体の河川流域計画思想に関しては, 公刊・ 行政資料・関連論文・文献・市民団体による機関紙・新聞記事・ 現地調查から田中及び渡良瀬川流域に関する記事を抽出し分析す る。計画思想の潜在的な側面として当時の状況を詳細に把握する ため関係者へのヒアリングを行った。
本研究では, 本章に続き 2 章で渡良瀬川と足尾鉱毒事件の経緯 を追い，3 章で田中の技術と立場そして「治水論」の内容につい て考察する。4 章では現代の渡良瀬川流域の市民団体による計画 思想 ${ }^{3)}$ を述へ， 5 章で田中の「治水論」を渡良瀬川流域の市民団 体の計画思想と比較し現代への継承を考察する。6 章で, 田中の 「治水論」の現代的意義についてまとめる。

\section{2. 渡良瀬川流域の経緯}

\section{(1) 足尾銅山の発展}

足尾銅山は 1550 年頃に発見され，1610 年江戸幕府の直山とな り, 当初江戸城や将軍ゆかりの増上寺, 日光東照宮など社寺の主 に銅瓦として使用されていた。

幕末には，休山同様の状況で明治政府に接収され，県営 ${ }^{4)}$ で操 業後, 1872 年民間に払い下げられた。1 877 年古河市兵衛が足尾 銅山の経営を開始し，洋式手法による鉱源開発を行った。1884 年新たな銅発見以後，急激に発展することになる。

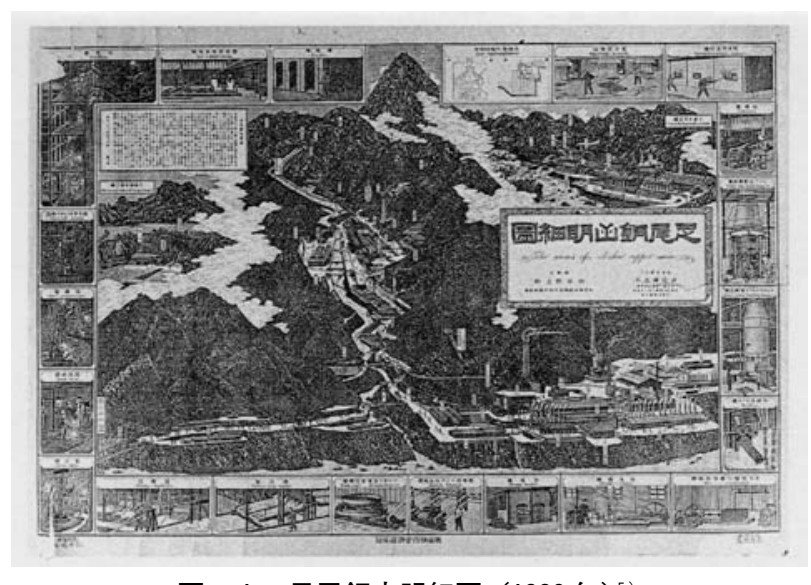

図-1 足尾銅山明細図 $(1889 \text { 年 })^{5}$

\footnotetext{
*東京大学大学院新領域創成科学研究科 ${ }^{* *}$ 東京大学大学院農学生命科学研究科
} 
その結果，製錬所などから排出される鉱毒による被害が 1878 年頃渡良瀬川の洪水とともに公害問題を引き起こした。1 880 年 代後半頃から鉱毒被害が顕在化していくこととなる。足尾銅山よ り流出する鉱毒から災害を受けた渡良瀬川下流域の農民たちが, その保障及び補償問題で請願運動を起こす。これらの被害の訴え や状況は, 田中により社会問題へ進展する。これが, 足尾鉱毒事 件である。

\section{（2）渡良瀬川流域の鉱毒被害}

鉱毒被害は主に，土壌水質污染と大気污染の 2 つである。

土壤水質污染に関しては，度重なる洪水が鉱毒を下流域に運び， 渡良瀬川沿岸各地で農作物や川魚などに影響を与えた。その後も 洪水の度に，鉱毒の被害が拡大化している。

大気污染は, 製錬所周辺及び周辺地区一体に影響を与え, 桑の 木が全滅し養虫ができなくなる。排煙に含まれる亜硫酸ガスが周 辺山林や峡谷に滞留し, 草木を枯らし, 全山荒廃裸地化すること により，土袞を侵食するなどの問題を引き起こした。

1897 年明治政府は古河市兵衛に対し, 大規模な「第三回鉱毒 予防工事命令」を発した。その内容は, (1)沈殿及びろ過池の設置 とその処理, (2)廃石, カラミの堆積場の新設及び適正管理, (3)脱 硫塔, 煙道の設置及び煤煙の適正処理, (4)坑水, 廃石などの流出 防止のための諸工事であった ${ }^{6)}$ 。しかし，予防工事実施後も鉱山 被害は沈静化せず，さらに広がりを見せ，1906 年の谷中村廃村 の事件へとつながっていく。

\section{3. 田中正造の「治水論」}

渡良瀬川流域の環境被害が拡大していく中で, 鉱毒反対運動を 展開した田中はどのような立場であったのか。さらに被害民を守 ることを前提として自然環境へどのような考え方を導き出したの か。田中の全集と関連論文から田中の技術と立場, 田中の「治水 論」について考察した。

\section{（1）田中正造の技術と立場}

田中は, 1841 年 11 月 3 日下野国小中村（現在の栃木県佐野市 小中町）に生まれる。17 歳で, 小中村六角家知行所の名主 ${ }^{7)}$ に 選ばれる。村人を指揮しての開田事業, 及び水争いによる権利の 責任者としての仕事を行っている。

1870 年, 江刺県花輪分局（現在の秋田県鹿角市）の官吏とな る。村々を巡回し農民の現実を克明に記録している。そして, 石 堤や砂堤, 竹を植栽する場合の心得について, 用水施設の図をい くつか書いている8)。

この名主と地租改正担当員の立場を通して, 地域の計画者とし ての役割を担う。そして, 治水技術者の心得や具体的な工法につ いては主に経験を通して独学で学んでいたと考えられる。

1878 年区会議員として, 政治活動を開始する。廃刊となった 栃木新聞 (現在の下野新聞)を 1879 年に再刊して編集長になり， 紙面上で国会の設立を訴えている。1 880 年に栃木県議会議員に 当選する。1 882 年に立憲改進党が結党され，入党している。 1886 年には県会議長を務めている。1890 年に第 1 回衆議院議員 総選挙に初当選する。1891 年に, 渡良瀬川の鉱毒の害を視察し, 第二回帝国議会においてはじめて「足尾銅山鉱毒の儀につき質問 書」を提出した。1 896 年に永久示談の不当性を追及する質問を 提出する。そして, 群馬県邑楽郡渡瀬村 (現在の群馬県館林市) の雲竜寺で演説を行う。

1897 年になると, 農民の鉱毒反対運動が激化する。1900 年川 俣事件が起こる。翌年田中は, 議員を辞職する。そして, 明治天 皇へ直訴を行うことになる。

1902 年に渡良瀬川下流に貯水池を造る計画が浮上する。はじ めに予定地となった埼玉県川辺村・利島村の計画は白紙となり, 翌年, 栃木県下都賀郡谷中村が貯水池になる案が浮上する。田中
は，1904 年 7 月から谷中村に住み始め, 以後 1913 年死去するま で，その主張のほとんどは貯水池計画への反対運動のため下流域 住民の立場から論じられている。

主に, 田中の立場は, 名主と官吏，次に議員，そして谷中村住 民としての立場と 3 つの時期に区分されるものと考察される。さ らに，名主としての住民をまとめる立場の責任感が生涯貫かれ， その技術が生かされ熟成していったと考えられる。

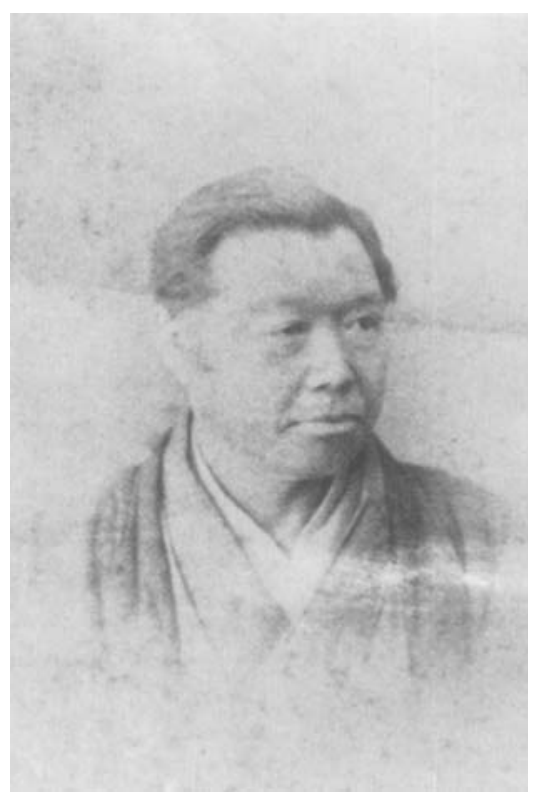

図－２田中正造 ${ }^{9)}$

\section{（2）田中正造の「治水論」}

渡良瀬川流域の自然環境が激変していく中で，鉱毒反対運動を 進めていった田中は，どのような「治水論」を論じたのか。

田中は，足尾鉱毒問題を下流域で発生している被害を含め認識 し，そして谷中村の治水問題のあり方を提示し，国の治水費に対 しても意見を述べている。終始一貫して被害民の立場に身を置き， 晚年には，河川の洪水への対応の考え方と技術を記述している。 主に，1909 年 2 月「治水論考」において「河川治水の本義は， 天然の地勢を順用するにあり。水勢の赴く所に任せて是れに干渉 せざる」としてその考えをまとめている。

田中は，源流域での森林伐採による影響だけではなく，利根川 の大規模な河川の直線化など人工的に流路を変更する手法を強く 批判し，江戸時代に改修された構造をも非難した ${ }^{10)}$ 。そして，洪 水を前提とした低水法を支持することとなる。それは，水の性に 対する深い洞察を必要とし，川の自然力の把握を基本としている。 さらに，治水のために河川流域に形成された古来天然の風致を損

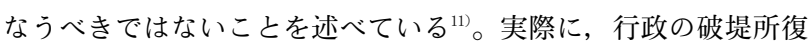
旧工事放棄もあり，1902 年住民をまとめ工事を行っている。地 図や図面むいくつか残されており，1909 年には栃木県にも河川 構造の改修案を提出している ${ }^{12)}$ 。記録として, 洪水による鉱毒被 害や流域の状況も克明に図面にしている ${ }^{13)}$ 。地形を読む技術につ いて，「宅塚は尚山水の一部なり。(中略) 主人に於ては全然天地 山水の理を知るものなし。断じて知るものなし。(中略) 庭園家 屋は天地の大なるあり。何を苦しんで之を造る事をせん。 $ل^{14)}$ と造 園の知識を利用する必要性を述べている。田中の河川技術の根本 は，名主・官吏時代に培った伝統的河川工法によるもので，その 考え方は晚年，地形水理を重んじている。

この河川技術に基づき，まず水源涵養のための治山を言及して いる。荒廃した山への植林と, 天然の地形に沿った治山の必要性 
を述べている。治水に比べて治山に関する深い考察の記述は少な いが，繰り返し乱伐による悪影響を訴えている。治山の技術につ いて，造園の心を持って行うことを良しとしている ${ }^{15)}$ 。

次に, 水の性に対する治水を基本として, 山河一体について言 及している。田中は, 洪水による流量の変化など，谷中村住民を 連れて利根川水系全体の治水調査を試みている。1910 年 8 月か ら 1911 年 1 月にかけて流域住民に対して聞き取り調查を綿密に 行うことによって流域全体を把握しょうとしたのである。

これらの河川技術と考え方に対応した人間活動として，「山河 川の骨脈組織に順じて太古より自然に作られたる村落の状態」昼) を本来のあり方としている。田中は，「人は此の天然の地形に依 りて定められたる天与の生活を楽しみたりき。」古今大小の事業, 耕作，漁猟一として此の天然の区画に依りて決せられざること無 し。」として,「土地に附著して生活する農民は妄りに移動せしむ べきものに非ず。」と述べている ${ }^{17}$ 。自然環境の働きに沿った人 間活動のあり方として, 河川の最も自然な状態を受け入れ生活す るべきであることを理想としている。

以上から, 田中の治水論は, 技術として「地形水理による伝統 的河川工法」を述へ，その根本となる考え方は「水源涵養として の治山」と「山河一体の治水」, そして「天与の生活を楽しむ人 間活動のあり方」の主に 4 つの側面にあると言える。田中の記述 は, 何れも各論ではなく, 相互扶助的に作用するように総合的に 論じられている。

\section{4 . 現代の渡良瀬川流域の市民団体における計画思想}

現代において渡良瀬川流域の市民団体 ${ }^{18)}$ は, どのような計画思 想を形成しているのか。本章では, まず渡良瀬川流域の市民団体 の特徵を述へ, 計画思想については市民団体の機関紙 ${ }^{19)}$ ・新聞記 事・雑誌記事・関連論文・現地調査より撮影した看板やポスター・

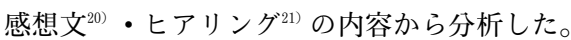

\section{（1）渡良瀬川流域の市民団体}

渡良瀬川流域で最初に設立された市民団体は, 渡良瀬川研究会 （1973 年設立）である。以後, 田中の学習を中心とする団体が 5 団体設立されている。

足尾に緑を育てる会（1996 年設立）は, 下流域の市民団体で ある渡良瀬川研究会と渡良瀬川にサケを放す会, 田中正造大学, さらに上流域の市民団体であるわたらせ川協会とあしおネイチャー ライフ 92', この 5 団体が事務局となり設立された。その後, 植 樹ボランティアは広まり, 一般の植樹ボランティアに加え, 地元 以外の市民団体が 9 団体存在している。

また, 渡良瀬遊水池をラムサール条約登録地にする会（2006 年設立）は, 谷中村の遺跡を守る会, 小山の環境を考える市民の 会, 渡良瀬の環境を考える会, 田中正造大学, 日本野鳥の会栃木 県支部，ラムサール条約湿地を増やす市民の会の 6 団体により設 立されている。

一方で，渡良瀬川流域の清掃を目的とした 10 団体，まちづく りを目的とした 5 団体が存在していた。他に渡良瀬遊水池を守る 利根川流域住民協議会（1990 年設立）や渡良瀬ネイチャリング アクト（1993 年設立）などの保全団体がある。

以上から, 渡良瀬川流域の市民団体は, (1渡良瀬川研究会にみ られる田中正造に関する学習の蓄積, (2)足尾に緑を育てる会と渡 良瀬遊水池をラムサール条約登録地にする会など, 相互交流によ り渡良瀬川流域の自然環境への働きかけとして必要な目的を達成 したい場合にその利害を共有した上で, 連携団体を形成, (3)田中 正造の学習を介さず保全団体を設立, これら 3 つの特徵があるこ とを述べた。

\section{（2）市民団体における河川流域計画思想}

渡良瀬川研究会を設立した F 氏は, 熊本県水俣市の水俣病の
現場をきっかけとして「鉱毒の教訓を伝えるため」田中の研究と 学習をはじめた。そして，「行動なくしては学んでいると言えな い」と実践を重視し，会員各々の立場で公害問題への支援活動を 行っている。渡良瀬川鉱害シンポジゥムをいくつかの団体が協力 して開催するなど，この団体の研究と学習の蓄積が，田中の学習 と流域を繋ぐ思想を形成している。

渡良瀬川にサケを放す会の 1982 年最初のサケの放流において, 渡良瀬川研究会の F 氏によってスローガン「足尾に緑を渡良瀬 に清流を」が提示された。はじめてサケの遡上が発見された際に は，石碑が建立された。この言葉は，足尾に緑を育てる会におい てもスローガンとして利用されている。

将来イメージとして, 鉱毒の被害を受ける前後の状況が記述さ れた「活ける渡良瀬, 死せる渡良瀬 ${ }^{22)}$ の言葉を象徴として描い ている。上流域の煙害の影響から廃村となる以前の松木村のよう に人々が山と共に生活できるようになるまでを望んでいる。また, 谷中村の遺跡を守る会は, 谷中村の遺跡に訪れた人々によるその 場への感想文の収集や, 谷中村住民に関する研究を続けるなど場 の記憶の保存を計画思想としている。また，裸地となった足尾地 域では, 感想文や草木塔の石碑を通して豊かな森のイメージが個々 のボランティアによって描かれている。

一方で, 渡良瀬遊水池を守る利根川流域住民協議会は, わたら せ未来プロジェクトの事業を 2001 年に立ち上げ，遊水池に関す る計画を立てている。現在の遊水池の自然環境を把握し, 豊かな 湿地としての機能の保全を計画思想としている。また，渡良瀬ネ イチャリングアクトは，鈞り場の維持を保全の背景としている。

一方で，渡良瀬川流域の清掃を目的とした団体，まちづくりを 目的とした団体，他に渡良瀬遊水池を守る利根川流域住民協議会 （1990 年設立）や渡良瀬ネイチャリングアクト（1993 年設立）な ど，特に 1990 年以降に設立された団体では，足尾鉱毒事件に関 する知識や田中研究からのアプローチではなく, 流域の自然環境 保全の観点から活動している点に特徴が見られた。

以上, 流域全体を繋ぐ活動に展開するための思想を形成し中心 となった団体が, 田中の学習を活動の目的とした渡良瀬川研究会 であることを述べた。また，初期の市民団体は，いずれの団体も 田中の思想もしくは足尾鉱毒事件を契機として設立されている。 比較的新しい団体は, 渡良瀬川や渡良瀬遊水池を利用して自然環 境を豊かに保全するという考え方によって, 活動を展開している 傾向があった。

\section{5. 田中正造の「治水論」と現代への継承}

前章において渡良瀬川流域の市民団体の活動は，田中の思想を 土台に学習を通して連携して活動を展開していることを述べた。

田中は, 「治水論」の考え方に則り, 根本的解決策として以下 3つを方針としている。

1 ）利根川を埼玉県葛和田の辺りょり南下させ，隅田川に流下 させること。関宿の棒出しを撤去すること。これは，15 世紀以 前の古来の姿に戻すことを目的としている。

2 ）江戸川を通して東京湾に流す方法。栗橋鉄橋の左右を切り 広げ水の停滞を防ぐこと。

3 ）水源地の山林を涵養すること。

これらは，自然の勾配差を利用した利根川南流論・江戸川主流 論である。田中の伝統的河川工法の考え方は，低水法を支持する ものであり, 水の性への洞察に加えて河川流域の地形に沿った河 川構造の実現を目指していた。

一方で現代の市民団体の活動は，まず，鉱毒事件の知識と旧谷 中村など場の記憶を保存すること，次に，鉱毒被害の影響の観察 に加えてサケを放流することと山林の涵養のための植樹による自 然環境を回復すること，さらに近年では，自然環境を保全するこ 
との 3 つにある

現代の市民団体が，河川構造へ田中の考え方や技術をそのまま 用いて活動することは難しい。田中が天然の自然環境に順じた保 護を目指したことと比較して, 現在の自然環境に順応している活 動とも言える。市民団体による田中の研究と学習, 及び谷中村の 遺跡を守る会の活動の中に, 歴史の保存と知識の蓄積という方向 性で，伝統的河川工法の手法は保持されていると考えられる。

次に, 植樹ボランティアは, 田中の「治水論」を学び, 治山を やり残した仕事として位置づけ継承をしている。田中の治山の考 え方は, あくまで治水を主眼とした水源涵養のための治山であっ た。さらに，治山には造園の心を持つことを勧めてはいるが，そ の具体的な技術や計画に関しては述べていない。現代の植樹ボラ ンティアの活動では，「下草刚りして植えた木の世話をすれば, やがて自然が回復していく実感があります。」と述べている。自 然環境を回復させていく活動の中に, 自然環境と人間活動のあり 方を論じている。現代において水源涵養の治山の考え方は, 足尾 に緑を育てる会を中心とした市民団体を設立して実践的に展開し ている。新たに植樹を通した活動の考え方として, 自然環境との 接し方や将来イメージなど治山の技術や計画が加えられている。

田中の山河一体の考え方は, 渡良瀬川研究会の F 氏の述べた 「足尾に緑を 渡良瀬に清流を」の言葉に象徴されている。渡良 瀬川にサケを放す会では, 渡良瀬川が清流に戻る証としてサケの 稚魚の放流と遡上の確認を行っている。この言葉は, 足尾に緑を 育てる会や渡良瀬遊水池を守る利根川流域住民協議会が, 活動の 方向性としている上流域と下流域の市民団体を繋ぎ合流させ活動 する方法の中に具体化されている。

そして, 田中の行った治水調查は, 住民意見の把握として重要 性がある。現代の市民団体では治水を目的とはしていないまでも， 活動を展開する前に，まちづくりの方向性など住民意見をまとめ るためのアンケートやヒアリングを行っている点に共通性がある。 田中は河川流域の人間活動について, 生業として自然環境と接 することを目指している。現代では, 将来イメージとして, 足尾 の裸地を生業の場としての山林へ回復することを描いている。し かし, 現代は, あくまでボランティアでの参加である。市民団体 の活動は, 余㗇やレクリエーションに近い感覚で自然に近づく傾 向として楽しむという考え方そのものを発展させている。

以上から, 田中の「治水論」は, 現代の市民団体の学習を通し て活動の中に継承され, さらに新たな展開と広がりが見られるこ とを指摘できる。つまり, 田中は鉱毒被害に対する生活保障のた めに徹底して保護論を述べていたのに対して, 現代の市民団体は, 鉱毒問題は残されていることを認識した上で回復や保全など環境 に順応する具体的な活動へと結び付けている。

\section{6. 結論}

結論は次のように導かれる。

田中の「治水論」は，主に「地形水理による伝統的河川工法」 「水源霃養としての治山」「山河一体の治水」「天与の生活を楽し む人間活動のあり方」の 4 つにあることを述べた。

現代において, 田中の綿密な学習を通してその考え方や思想を, 活動に展開させた団体の中心が渡良瀬川研究会であることを述べ た。渡良瀬川研究会は, 田中の「治水論」を継承するために内容 を厳密に理解した上で, 活動の中で自然環境の回復や治山治水論 として広義に捉えられたものと考えられる。そして, 新たな展開 として田中の学習に主軸を置くのではなく, 自然環境保全を目的 とした市民団体が発生している。これらの各団体は, 役割分担し て各々連携しながら活動することによって, 田中の「治水論」の 思想を繋いでいると言える。

田中が自然環境の働きに沿った治水と人間活動のあり方をあく
まで保護論として述べたのに対して，現代の市民団体では，過去 の自然環境に向けた回復と同時に, 自然環境に順応する傾向が見 られるものと考えられる。

我が国の河川計画は, 1896 年の河川法以後, 近代科学技術を 推進し, 堤内地の流水のみを扱い, 河川を直線化してなるべく早 く海まで流過させることを目指すこととなる。また，近年の治山 は, 森林法及び一部砂防法が適用される。その管轄は, 土地利用 によって分断されており, 総合的に管理するという側面において 脆弱性がある。その点, 田中の「治水論」は, 主に河川法成立以 前の伝統的な考え方を主に重んじている。総合的な河川計画の理 論は，現代において参考になる観点が多くあるものと考えられる。

また，現代の河川と人間活動のあり方は，人は自然から離れ， 関係を築きにくい傾向にあると言える。ボランティアによる自然 環境活動のあり方は，田中の「治水論」における比較考察の結果 から伝統的河川工法の考え方に近いものである可能性があり, 今 後の研究課題である。

謝辞 : 足尾に緑を育てる会の関係者の皆様, 渡良瀬川研究会の布 川了氏, 田中正造大学の坂原辰男氏に, 心からの感謝を捧げる。

\section{補注及び引用文献}

1）小松裕（2001）：田中の近代：現代企画室，576-595

2 ) 中村愛子・下村彰男 (2009) : 足尾砂防地区緑化事業の植樹ボランティ アにおける計画思想に関する研究：ランドスケープ研究 72(5)，455458

3 ）中村は，河川流域の保全過程における市民団体の活動を広義の計画と して捉え, 各市民団体の位置づけ, 内容, 参加者各々の発言から計画 思想を分析。（中村愛子・熊谷洋一（2006）：野川の保全過程におけ る計画思想に関する研究：ランドスケープ研究 69(5), 361-364)

4 ）足尾銅山は，1868 年日光県の所管，1871 年廃藩置県により栃木県の 所管となる。

5 ）栃木県博物館第 71 回企画展 - 佐野市郷土博物館第 37 回企画展 （2007）：特別企画展「田中とその時代一天皇直訴 100 周年一」：栃 木県博物館・佐野市博物館, 37

6 ）脱硫塔の建設等の古河の対応も亜硫酸ガスを完全に取り除くことはで きず，1956 年に紛鉱処理主体の自溶製錬が開始される。翌年に前橋 営林局，栃木県林務部，建設省（現在の国土交通省）渡良瀬川工事事 務所の三者協議により事業分担を決め本格的な植樹事業が始められた。

7 ) 名主とは, 江戸時代に, 有力農民・町人から任命され町や村の公務を 行った責任者。現在の町村長にあたる役目。

8 ）田中正造（1977）：田中正造全集第 9 巻：岩波書店，83-94

9 ) 前掲書 5), 20

10）田中正造（1978）：田中正造全集第 12 巻：岩波書店，550-551

11）前掲書 10), 254

12）前掲書 5), 100

13）田中正造（1980）：田中正造全集第 5 巻：岩波書店，467-482

14）前揭書 10$), 237-238$

15）田中正造（1977）：田中正造全集第 13 卷：岩波書店，466

16）田中正造（1977）：田中正造全集第 5 巻：岩波書店， 17

17）前掲書 16$), 15$

18）市民団体は，活動内容を一般に公開していることを前提として，渡良 瀬川を活動場所の対象としており，自発的な団体であることを条件と した。各団体の HP 及び現地調査から，45 団体を抽出した。

19）市民団体の機関紙は，渡良瀬川研究会の「田中正造と足尾釷毒事件」 「わたらせ川通信」, 田中正造大学の「救現」「田中正造大学通信」, わ たらせ川協会の「わたらせ川」「わたらせ川協会事務局通信」である。

20） 1999 年から 2006 年にかけて体験植樹に参加した小学校 118 校から国 交省及び育てる会に自主的に寄せられた感想文。

21）上流域の調查は，2007 年 5 月 7 日から 13 日， 5 月 18 日から 6 月 16 日にかけて体験植樹に参加した関係者，イベント毎の一般ボランティ ア, スタッフ会議への参加, 育てる会スタッフ 10 名, 足尾町住民 5 名に対し筆者がヒアリングを行った。

下流域の調查は, 主に 2007 年 8 月から 2009 年 8 月にかけて, シンポ ジウムやイベントへの参与観察, スタッフ数名へのヒアリングを行っ た。

22）東海林吉郎・布川了（1977）：亡国の惨状 復刻版：伝統と現代社, 31-33 